\title{
An Analysis of the Positioning of the Vientiane Saysettha Development Zone in the Background of the Belt and Road Initiative
}

\author{
Based on the Platform Economic Theory
}

\author{
Xiangshi Mao* \\ International Business School \\ Yunnan University of Finance and Economics \\ Kunming, China \\ 809390193@qq.com \\ Huanbin Liu \\ International Business School \\ Yunnan University of Finance and Economics \\ Kunming, China \\ 939765326@qq.com
}

\author{
Yuanyuan Zhuang \\ International Business School \\ Yunnan University of Finance and Economics \\ Kunming, China \\ 1094359655@qq.com \\ Yan Lee \\ International Business School \\ Yunnan University of Finance and Economics \\ Kunming, China \\ 369011652@qq.com
}

\begin{abstract}
This article introduces the investment background of the Vientiane Saysettha Development Zone, reviews the construction history of it and analyzes in depth the success of the Vientiane Saysettha Development Zone positioning which will be taken as a reference for overseas investment of Chinese enterprises in the construction of the Belt and Road.
\end{abstract}

Keywords-positioning; platform; the Vientiane Saysettha Development Zone

\section{INTRODUCTION}

The current world economic and political situation is stable and peace and development are still the theme of the times. The strengthening of regional economic cooperation has become an important driving force for the development of the world economy. China thus proposed the Belt and Road Initiative to strengthen economic and cultural exchanges and cooperation with countries along the route to promote common development. Under the background of the Belt and Road Initiative, Yunnan enterprises have also actively carried out foreign investment cooperation by virtue of their location and other advantages.

The Vientiane Saysettha Development Zone, which is invested by Yunnan Provincial Overseas Investment Co., Ltd. and the government of Vientiane, Laos, is a model. The Vientiane Saysettha Development Zone defines the comprehensive development zone as "one city and four zones", namely: Vientiane Industrial Ecological New City, International Capacity Cooperative Bearing Area, China-Laos Cooperative Development Demonstration Area, Vientiane New City Core Area and Harmony Habitat. It is precisely the precise positioning of the development zone that not only meets the actual conditions of the two countries at the current stage, but also meets the needs of both parties for long-term sustainable development. At the same time, it attracts target enterprises to settle in one after another and realizes a win-win situation between the enterprise and the development zone, and also realizes the two A win-win situation for the country.

\section{BACKGROUND OF THE VIENTIANE SAYSETTHA DEVELOPMENT ZONE}

\section{A. The Belt and Road Initiative}

In today's world, the political and economic environment is stable, and all countries are committed to peace and development. The strengthening of regional economic cooperation and exchange has become a new driving force for the development of the global economy. Our country has become a manufacturing center in the world by virtue of its reforms and its advantages in labor, resources, etc. It has accumulated huge foreign exchange reserves and has comparative advantages in terms of manufacturing technology, capital, experience, and even excess production capacity in steel and textile industries. As China's market-oriented reforms continue to deepen and the degree of opening to the outside world further increases, it is a firm defender of the global free trade system and the open world economy. At the same time, developing countries in Central Asia, South Asia, Southeast Asia, and East Africa have a good momentum of development and have a strong demand for capital and technology.

In September and October 2013, President Xi Jinping proposed the Belt and Road Initiative (the Silk Road Economic

*Corresponding author 
Belt and the 21st Century Maritime Silk Road) to comply with the world's multi-polarization and economic globalization..

In the background of the Belt and Road Initiative, China's economic, trade, and cultural cooperation with countries along the route has been fruitful and many major cooperation has been achieved. In the first 11 months of 2017, Chinese enterprises directly invested 12.4 billion U.S. dollars in the countries along the line, and the value of newly signed contracted projects was 113.5 billion U.S. dollars, an increase of $13 \%$ year-on-year; the actual investments of China's countries along the routes were 5 billion U.S. dollars, and more than 3,500 new enterprises were established. As of 2017, a total of 16 free trade agreements have been signed involving 24 countries and regions. Chinese enterprises have promoted the establishment of 75 overseas economic and trade cooperation zones in countries along the Belt and Road, accumulatively invested more than 270 billion U.S. dollars, attracted nearly 3,500 enterprises in the region, and paid taxes and taxes of the host country of 2.2 billion U.S. dollars, creating nearly 210,000 jobs for the local people.

\section{B. Analysis of Economic Environment in Laos}

Laos which is located at the center of Indochina with area of 23.68 square kilometers and more than 6.8 millions populations, bordering Yunnan, China, is located in the ChinaASEN free trade area, the greater Mekong sub region in the heart of ASEN countries. It is the connection between China and other Southeast Asian countries. Laos is the only countries in southeast Asia that do not have an outlet are roads, water and air transport, and the Mekong river can carry 20 tons to 200 tons of ships. The total mileage of Laotian highway is about $47,000 \mathrm{~km}$, carrying $80 \%$ passenger and freight volume.

Laos has a GDP of us $\$ 15.9$ billion in 2016, with a per capita income of us $\$ 2,150$. Vientiane, the capital of Laos, is the national economic and cultural center, with a population of 828,000 in 2016 , with a population density of only 52 people per square kilometer. Industrial production accounts for about three quarters of the country. Laos is mainly agricultural and its industrial base is weak. Promote innovation and open since 1986, the adjustment of economic structure, namely, agro forestry, industry and services, the combination of priority to the development of agro forestry, the rapid development of service industry in recent years, in 2015, agro forestry, industry, service industry proportion were $23.3 \%, 28.8 \%$ and $39.8 \%$ respectively.

Laos has abundant labor force and low labor cost, excellent climate, abundant water and solar energy resources; the forest area is about 17 million hectares, and the national forest coverage rate is about $50 \%$. The agricultural development condition is better, coffee, rice, tobacco, potato and other products are rich; there are gold, copper, tin, lead, potassium, salt and other mineral resources in China. So far, gold, copper, coal, potash and coal have been mined. Agriculture, forestry and its processing industry, mining industry, water and electricity industry and tourism industry are all key areas of investment potential in Laos.

China is the second largest trading country in Laos, with bilateral trade volume reaching us $\$ 2.34$ billion in 2016 .
China's investment in Laos has exploded, and Laos ranks among the top countries in China's investment in Southeast Asia and the Belt and Road. By the end of 2015, the stock of direct investment in Laos by Chinese companies was $\$ 48.42$ billion, a 15-fold increase from the $\$ 302$ million in 2007. In 2015, China approved 185 foreign investment projects approved by Laos, with a total value of $\$ 2.54$ billion, ranking first, twice as much as Thailand. According to the filing results of the overseas investment enterprises of the ministry of commerce, there are a total of 166 Chinese enterprises to invest in Laos. Investment industry, Chinese enterprises to invest in Laos is mainly involved in leasing and business services, power/heat/gas and the production of water supply industry, mining industry, construction industry, animal husbandry, fishery and the real estate industry, including key areas are mining, according to the first place, which accounts for more than $50 \%$, the total investment followed by electricity and agriculture.

Laos is a member of the least developed countries identified by the United Nations, enjoying the privileges granted by the United Nations, such as preferential market access and commodity trade preferences. The 38 countries and regions in the world regard Laos as the beneficiary country of its GSP. China has given Laos special preferential tariff treatment to exempt 459 kinds of Laos goods from their import duties. Laos, as a member of the WTO, enjoys the most favored nation treatment and national treatment given by other member states. The political situation in Laos is stable and has high political mutual trust with our country. China is the largest neighbor of Laos, the same is a socialist country, and the two countries have a long tradition of friendship. In recent years, the friendly interaction and cooperation between senior and senior leaders of the two countries have been strengthened, and the economic and trade cooperation between the two sides has been deepened. The economic development of Laos is good and the degree of modernization is gradually increasing.

\section{PROJECT BRIEF}

The Vientiane Saysettha Development Zone is the China and Laos governments jointly determine national cooperation projects between the two countries. It is Laos' national economic zone, also China's only national foreign trade and economic cooperation zones in Laos which is China's early harvest program of strategic plans. Total investment of that is about \$350 million, covers an area of 1149 hectares, is located in the Laotian capital, Vientiane city, in northeast of $21 \mathrm{~km}$ race Saysettha county. And the county covers an area of 10 square kilometers, is the core of Vientiane new area.

Development zone operation subject is Laos and China Joint Investment Co., Ltd. (LCC), the company's total equity of $\$ 128$ million, including: Yunnan the shotgun to spend $\$ 98$ million, accounting for $75 \%$ of the total share capital; the Venetian city government has contributed $\$ 30$ million which account for $25 \%$.

At present, the development zone in the first four square kilometers has finished infrastructure constructions such as water power, communicating network which can fully meet the needs of the enterprises in the park. The park has 20000 square 
meters of small and medium-sized enterprise incubator customer service center of 2000 square meters providing comprehensive support for the development of small and medium-sized enterprises.

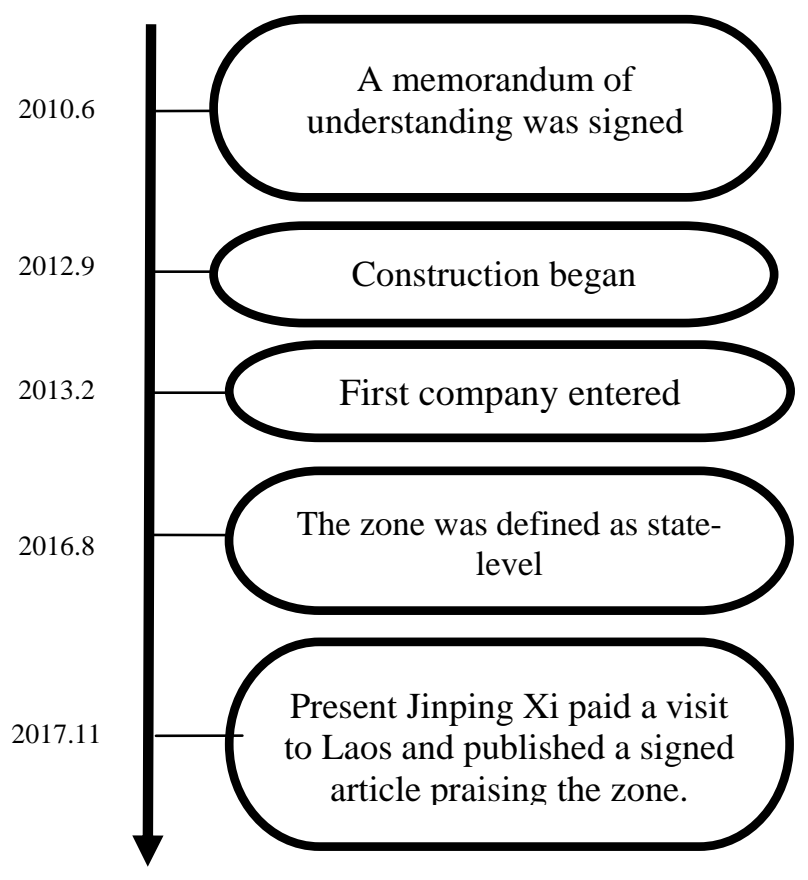

Fig. 1. Significant project process nodes

\section{RELATED THEORIES}

\section{A. Platform Economic Theory}

The Vientiane Saysettha Development Zone mainly composed of Chinese investment, it is a Laos-China cooperative construction projects. This paper argues that the platform structure as shown in the figure below [1].

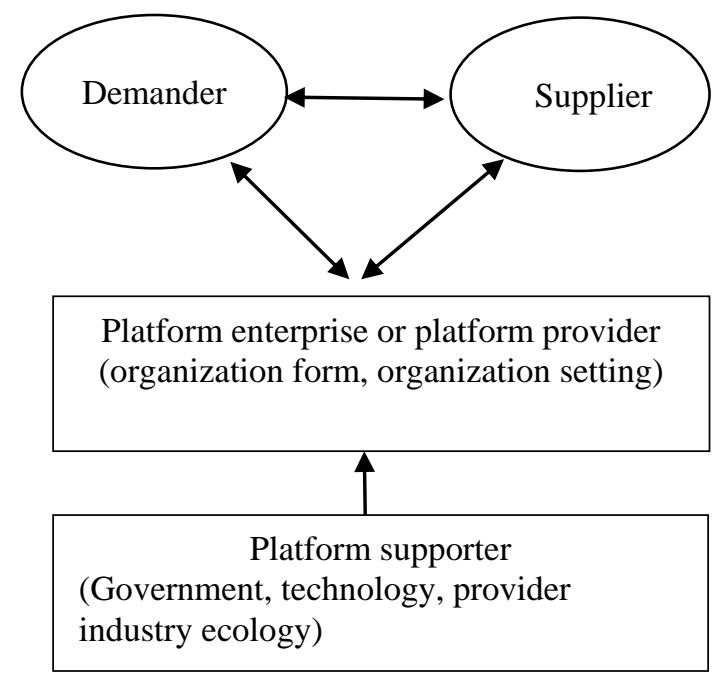

Fig. 2. Platform structure
Based on the theory above, we can draw the platform contracture figure.

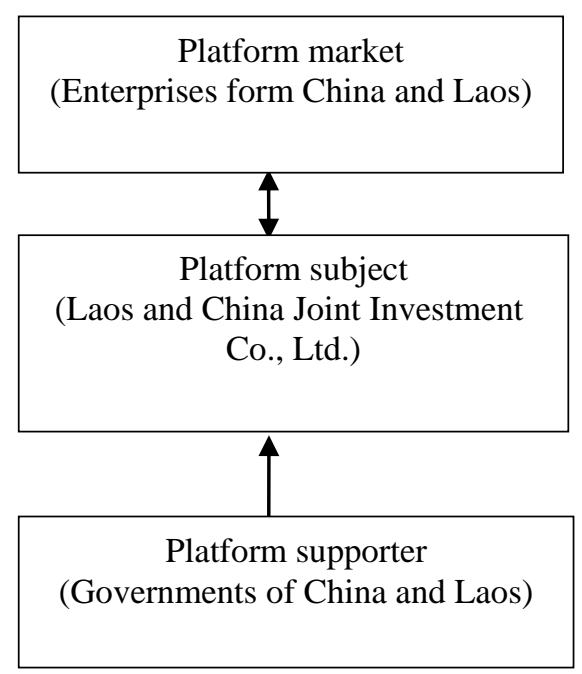

Fig. 3. Platform structure of the Saysettha Development Zone

\section{B. Other Support Theory}

\section{1) Theory of Industrial Ecology}

Industry ecology refers to the natural ecological organic circulation mechanism, to a specific geographical space industry system coupling optimization between nature system and society system, to make full use of resources, eliminate environmental damage, coordination of natural social and economic sustainable development.

\section{2) Theory of Marginal Industry Expansion}

Japanese scholars island of marginal industry expansion theory provide the basis for international cooperation capacity he thinks some of the industry in the country in a country have or will soon lose their development space, (or will be at a disadvantage is the status of both), become the country's marginal industry, while in other countries may be in the same industry dominance or potential advantage position, so that a country should have been in or near its beginning at a disadvantage position of marginal industry foreign direct investment can play investment country and host country's comparative advantage, benefits to both sides.

\section{3) The Theory of Cooperative Exploit}

Cooperation exploit of Laos is based on the premise of both sides to participate in a brief, by signing the agreement, the investment by the Chinese side of the country's mineral resources exploration and development, and bear the major investment risk, the results of the two sides in accordance with the agreement to share cooperative development based on the side of the advantage of capital technology experience, one party has the resources superiority, thus cooperation development, play to their respective comparative advantages, realize the win-win of both parties.

4) The Theory of Productive and Residential Integration

Producing fusion is "to promote the city, city to city produce, city fusion", make industry and urban integration 
development, on the basis of city, bearing industry space and the development of industrial economy, with industry as the guarantee, drive urban update and perfect service facilities, further raising land value, in order to achieve dynamic between industrial city people Sustained development pattern From two aspects of urban development and people's life, focus on two goals as the "planning, building industry, comprehensive livable city", many cities have become the development of new ideas. Units

\section{POSITIONING OF VIENTIANE SAYSETTAHA DEVELOPMENT ZONE}

Project positioning for the overall planning of "a city four areas", namely: Vientiane metro international industry ecological carrying capacity cooperation area cooperative development of a brief demonstration area of Vientiane new town core area and harmonious living environment of the habitable zone.

\section{A. Vientiane Industrial Ecological New City}

\section{1) Analysis of Industry Ecological Advantage Based on} Platform supporter

a) China's Industrial Ecological Analysis:China in recent years in the early stages of the domestic industrial upgrading and structural adjustment, in yunnan region has the traditional advantages of textile and garment processing and machinery manufacturing and other industries to Laos, the advanced production technology of industry organization and management experience, and Laos cooperation can not only benefit for the economic development of the Lao and then get rid of the barriers to trade and export quota restrictions policy constraints, in addition, the handicraft souvenirs such as processing and production of overall labor structure model for Laos.

b) Ecological Analysis of the Laotian Industry:Laos is a traditional agricultural country, with the largest proportion of agricultural output, but low mechanization degree; The industrial base is weak and the processing industry is mainly produced by primary products. Service industry started late, lack of innovation, lack of competitiveness.

2) Industrial Ecological Analysis Based on Platform Subject

This multidimensional system of production, including production technology service dimensions labor dimensions related infrastructure development of public or government dimensions is based on the capital economy center in Vientiane, according to the "industrial park and new city development" mode of comprehensive development to promote new town construction industry development.

\section{3) Industrial Ecological Analysis Based on Platform} Market

The internal and external advantages of the integrated development zone reflect a new industrial development model and a new form of industrial layout to attract enterprises from China and Laos.
As of July 2017, the tower comprehensive development zone has invested $\$ 360$ million, a period of 4 square kilometers has been completed the construction of infrastructure, from China to Laos have eight countries and regions such as Singapore, Malaysia Thailand Austria's 39 companies signing in industries involved in clean energy investment Livestock products processing power products manufacturing feed processing of tobacco processing and building materials science and technology, logistics, warehousing, etc.

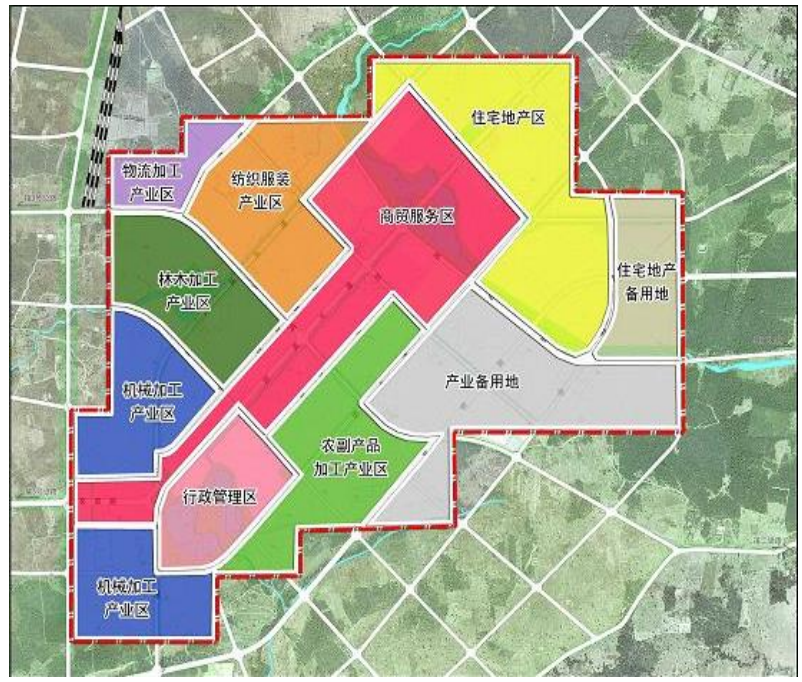

Fig. 4. Industrial zoning map of the development zone

Source: ministry of commerce of the People's Republic of China

\section{B. International Capacity Cooperation Bearing Area}

1) Analysis of the Advantages of Production Capacity Cooperation based on Platform supporter

a) China's Overcapacity Analysis:In recent years, our country economy enters the new normal, macro economic growth is slowing, insufficient aggregate demand, relying on the advantages of the labor resources in our country, some of the industry experienced rounds of capacity expansion, increasingly prominent structural contradictions, overheated investment demand greater than supply lead to overcapacity, especially steel textile real estate and other traditional industry overcapacity "One Belt And One Road" put forward to solve the domestic overcapacity adjustment of industrial structure provides the valid path In China all the way to the neighborhood Along the country can provide manufacturing transfer capacity, and the other countries area all the way along the route can be released in cooperation with China agricultural ability and the potential energy and mineral resources, etc

b) Analysis of capacity carrying capacity in Laos:Laos is in the process of constantly optimizing and upgrading the industrial structure. This is mainly reflected in the backward infrastructure in Laos. The demand for infrastructure construction is huge. At the same time, there is a great deal of demand for cement, stone and other building materials and machinery equipment, electricity and steel. In addition, agriculture is a traditional industry in Laos. In the process of promoting agricultural mechanization, the demand for agricultural machinery and advanced agricultural technologies 
is also increasing. There is an urgent need for foreign direct investment in these areas.

\section{2) Analysis of Capacity Cooperation Based on Platform} Subject

The Vientiane Saysettha Development Zone conforms to the guidance of the Belt and Road initiative and is positioned as an international capacity-bearing zone. It undertakes surplus production capacity for other countries, but it is a necessary industry for Laos, and it is supported by both parties for mutual benefit and win-win.

This kind of capacity cooperation helps to bring into play their respective comparative advantages. This is a win-win and multi-win result. Firstly, the cooperation in production capacity is complementary to make up for the insufficiency of capacity provision and utilization in related countries. Secondly, capacity cooperation can make the development achievements of China's reform and opening up for many years to spill over and spread along the Belt and Road. Thirdly, China's transfer of production capacity to countries along the Belt and Road can achieve economic benefits that trade cannot achieve. Fourth, the transfer of production capacity is conducive to the economic development of countries where production capacity is transferred.

\section{3) Analysis of capacity cooperation based on platform market}

Laos has attracted foreign processing, manufacturing, and service industries to achieve better results and will continue to introduce them. The Lao National Assembly passed the government's economic and social development plan for 2018, and its economic growth in 2018 will be no less than 7\%. It will realize exports of US\$5.015 billion, imports of $\$ 4.978$ billion, and per capita annual income of US\$2,536. As a host country, these cooperation zones have attracted more Chinese companies to invest and build factories. They not only play an important role in cultivating their respective industries, increasing employment, raising taxes, and expanding export earnings, but also strongly promote its economic development.

\section{China-Laos Cooperative Exploit Demonstration Zone}

1) Analysis of Cooperative Exploit based on Platform supporters

On the one hand, Laos has rich hydropower resources and biological resources, but it is limited by technology and funds and cannot exert its resource endowment advantage. On the other hand, Laos has a weak industrial base and cannot meet its national needs. This restricts its economic development, especially energy and chemical industry, high-tech industry. And its water, electricity, and transportation facilities are incomplete, and its infrastructure is very backward.

\section{2) Analysis of Cooperative Exploit based on the platform} Subject

The Vientiane Saysettha Development Zone is positioned as a Sino-Lao cooperation development demonstration area, providing support for the development of Sino-Lao cooperation, including taxation, one-stop service, and employee training and so on. The park plans to have forest processing areas, agricultural and sideline product processing areas, and manufacturing and processing areas. The introduction of relevant enterprises from China and other countries will strongly promote Laos to exert its advantages in resource endowments, and to a great extent improve the domestic energy and chemical industry in Laos and promote the status quo in a great extent. The development of the Laos energy and chemical industry has a profound and significant impact on the national economic development of the Laotian.

\section{3) Analysis of Cooperative Exploit based on Platform} Market

China's chemical industry, manufacturing industry, and mineral development industry are more developed and have the strength and motivation for overseas investment. These types of enterprises will enter the development zone actively and cooperate with Laos to develop their domestic resources. Take the oil industry as an example. At present, Laos has no oil industry. There is neither a proven crude oil reserve nor any currently operating refineries. So the domestic consumption of gasoline and diesel depends entirely on imports. The main importing countries are Thailand and Vietnam.

Under the leadership of the Belt and Road initiative, the first oil and petrochemical project in Laos, which is to be built by a Chinese-Lao joint venture, is expected to be completed and put into operation in the Vientiane Saysettha Development Zone in mid-2018. After the project is completed and put into production, it will achieve annual processing production with 800,000 tons of gasoline; it will meet $60 \%$ of Laos' fuel demand and become one of the largest modern industrial enterprises in Laos.

\section{The Core Zone of Vientiane New City and Harmonious Habitat}

1) Analysis of Productive and Residential integration based on the Platform supporter

Located 17 kilometers northeast of the main urban area of Vientiane, the Laos capital, the Saysettha Comprehensive Development Area is the core area of Vientiane New City and has a good location advantage. With the development of Laos's urbanization and the expansion of Vientiane City, it will be the new city of Vientiane core area. The development zone enjoys convenient transportation. The positioning of the Vientiane Saysettha Development Area as a core area is to improve the function of the new city of Vientiane, enhance the image of the new city, form a gathering place for government affairs, commerce, and corporate headquarters, and create the core area of the new city of Vientiane.

2) Analysis of Productive and Residential integration based on the Platform Subject

Capital Vientiane is Laos's main urban population gathering place and political and economic center. In recent years, with the increase of income and consumption level of the Laotian people, real estate commercial real estate, office buildings and residential apartments have developed rapidly.

As shown in the table below, the population growth rate of Laos from 2011 to 2015 generally shows an upward trend. The proportion of urban population in the total population has been on an upward trend. This shows that the level of urbanization 
in Laos has been steadily increasing, the number of cities has continued to increase, and the size of cities has continued to expand, and more and more Lao's population has gathered in cities. Vientiane, as the capital of Laos, will inevitably attract more people. Based on this, residential development projects in development zones have more potential for development.

TABLE I. POPULATION GROWTH RATE AND PROPORTION OF URBAN Population to TOTAL POPUlation OF LAOS, 2011-2015

\begin{tabular}{|c|c|c|}
\hline Year & $\begin{array}{c}\text { Population } \\
\text { growth rate (\%) }\end{array}$ & $\begin{array}{l}\text { Proportion of urban } \\
\text { population to } \\
\text { population ratio (\%) }\end{array}$ \\
\hline 2011 & 1.68 & 34.252 \\
\hline 2012 & 1.65 & 35.368 \\
\hline 2013 & 1.63 & 36.469 \\
\hline 2014 & 1.64 & 37.551 \\
\hline 2015 & 1.67 & 38.614 \\
\hline
\end{tabular}

The development zone plans residential real estate areas and plans to introduce high-quality residential housing projects. The zone pay attention to ecological and environmental protection, and improving the level of living, education, medical, shopping, health care, leisure and other ancillary facilities. The zone is livable areas with a beautiful environment and a fully equipped and harmonious living environment to achieve a dynamic and continuous upward development model among industries, cities, and people.

3) Analysis of Productive and Residential integration based on the Platform Market

The continued prosperity and development of real estate in China also fostered a number of powerful real estate development companies. These real estate development companies have an efficient management model, advanced construction technology, rich experience in organization and management, and started to actively invest in foreign countries and take the path of internationalization.

\section{SUMMARY}

There are 3 successful experiences in this case worthy of reference for all companies that invest in foreign countries :

- The development zone is deeply aware of its essence as a platform, take all construction elements of platform into deep analyze. The Vientiane Saysettha Development Zone starts with the components of the platform, starting from the three directions of the platform supporter, the platform subject, and the platform market, and combines the functions of the various parts of the platform to develop positioning.

- The positioning of the development zone is based on the national conditions of both countries. And under the international trend of strengthening regional cooperation, the Belt and Road construction will help to achieve mutual benefit and win-win results. China has advantages in terms of capital, technology, experience, and even excess capacity in steel, real estate, textile, etc.; Laos is at a time when its industrial structure is optimized, and domestic resources are lacking in development, which requires the introduction of capital and technology.

- The development zone aims at long-term operation, combines the development of itself with the national development plan, takes the complete industrial ecology and integration of production and residence as the guide and takes the road of sustainable development.

In addition, from the review of the development history of the Vientiane Saysettha Development Zone, it can be seen that the government-level communication and support also has played a key role in promoting the development. The Belt and Road Initiative provides a good external environment and favorable policy support for economic and cultural exchanges between China and the countries along the route. This is an opportunity for China and the countries along the route to develop together. It is also the best opportunity for Chinese enterprises to go abroad. Enterprises should also review the situation, seize the opportunity, learn from the successful experience of this case, carry out outward foreign investment, and start international operation actively.

\section{ACKNOWLEDGMENT}

We would like to extend our deep gratitude to all those who have offered us practical, cordial and selfless support in writing this thesis, especially our teacher Professor Yan Lee who help us with a dedicating heart.

\section{REFERENCES}

[1] Jin Xu, Platform Economics: Theory and Practice of Platform Competition, Shanghai: Shanghai Jiao Tong University Press, 2007.

[2] Rochet Jean, Charles Triole Jean, Platform Competition in Two-sided Markets [J], Journal of European Economic Association, 2006, No.1.

[3] Elsenmann T.G. Parker and M. Van Alstyne, Opening Platforms: How, When and Why? [R].Harvard Business School Entrepreneurial Management Working Paper No.09-030, 2009.

[4] Ares, R.U., Industrial Metabolism: Theory and Policy[A].Allenby, B.R., Richards, D.J. The Greening of Industrial Ecosystems[C].Washington: National Academy Press, 1994

[5] Lianyin Hong, Ruxuan Huan, "Rethinking and Adjusting the Functiona Orientation of Shanghai Free Trade Area--An Analysis Based on Platform Economic Theory," International Business Research, vol.1, 2017, pp:54-64

[6] Ling Lee, "Platform Economic Development and Government Regulatory Model Reform,” Economist, vol. 7, 2015.

[7] Jianyong Shi, "Optimizing the New Economic Structure of Industria Structure: A Microeconomic Operational Mechanism of Platform Economy," Shanghai Economy Research. Vol. 8, 2013, pp: 85-89.

[8] Juan Gao, Changhong Lv, Wenping Zhou, "Singapore Free Trade Zone Operation Experience and Enlightenment," World Shipment, vol. 3, 2014.

[9] Xuejing Lee, Study on the Platform Competition in Bilateral Market, Shanghai University Press, 2014.

[10] Shanchen Xia, "China (Shanghai) Free Trade Zone: Positioning of Ideas and Functions," Journal of International Economic Cooperation, vol. 7 , 2013 . 